\title{
Monuments as Commitments: How Art Speaks to Groups and How Groups Think in Art
}

\author{
C. Thi Nguyen \\ (This is a pre-print. Please cite the final version, published at \\ Pacific Philosophical Quarterly: \\ https:/ / doi.org/10.1111/papq.12279 )
}

Art can be addressed, not just to individuals, but to groups. Art can even be part of how groups think to themselves - how they keep a grip on their values over time. I focus on monuments as a case study. Monuments, I claim, can function as a commitment to a group value, for the sake of long-term action guidance. Art can function here where charters and mission statements cannot, precisely because of art's powers to capture subtlety and emotion. In particular, art can serve as the vessel for group emotions, by making emotional content sufficiently public so as to be the object of a group commitment. Art enables groups to guide themselves with values too subtle to be codified.

Art can be addressed, not just to individuals, but to groups. This is not the usual conception of how art works. Let's grant, for the moment, that much art does in fact address itself to individuals in the familiar way. This is not, however, the end of the story. Art can also speak to communities, institutions, and nations. The mural calling on a community to take care of the neighborhood; the patriotic statue I place in my front yard - these address groups, urging them to adopt some particular value or stance. And in some cases, art can play an even more integral role in the inner lives of groups. Art can play a part in how groups think to themselves, and how groups commit themselves to difficult-to-express values. An artwork can stand as the public instantiation of an emotion, and so enable a group to guide 
itself by that emotion. In short, art can make it possible for groups to have emotionally-laden values and commitments.

This is not how we usually think of group commitments. In most recent theoretical accountings, group commitments usually take a more conventionally propositional form. In the standard picture, a group hangs onto its values and principles by setting them down as explicit statements. The United States has the Constitution and its legal extensions; a corporation has a charter and rules to guide its operation. But such explicit statements are notoriously poor vessels for some of the richer and subtler forms of value. Is this simply a limitation on group-level agency and deliberation? I suggest otherwise: it is simply that groups must turn to other kinds of expression to guide themselves by such subtle values. This is where groups can, and do, make use of certain kinds of art. Art enables groups to keep a grip on emotionally-laden understandings of the world and to commit themselves to subtler expressions of value, ends, and reasons. Art can play a vital role in the inner lives of groups.

Consider a group agent: a group of individuals organized such that we can attribute intentions, actions, and sometimes even values to the group. By most modern accounts of group agency, we can attribute an attitude to a group when its members have appropriately and publicly coordinated around that attitude (Toumela 2007; List and Pettit 2011; Tollefsen 2015; Gilbert 2013). These accounts typically put a publicity constraint on group intentions. A group intention must be shareable between individuals before it can be taken on as the group's. One might then worry that the publicity constraint makes emotionally-laden group intentions impossible because such emotional content is impossible to publicize. This is precisely where art can come in. Art, famously, is good at presenting and expressing emotions. If a group wanted to constitute itself around core values that are crucially emotional, then what we would expect to find, at its center, artworks and their kin.

This possibility has been neglected, I suspect, because it takes us directly into a dead space in our theoretical understanding of art. This is the possibility that art can be addressed, not primarily to individuals, but to groups. Let us call this category art for groups. In my eyes, plausible candidates include monuments, memorials, murals, street art, anthems, urban design, parades, and fashion. You'll notice that these are hardly paradigmatic forms of art and artwork. This is no accident. The traditional understanding of the practices of art, at least 
in the recent Western European aesthetic tradition, has been profoundly individualist. Usually, in this aesthetic tradition, the paradigmatic art encounter is between individuals or something very close to it; art is created by a lone artist (or small group) for individual consumption.

Only very recently has aesthetic theory begun to come to terms with its individualist bias, and to think about groups in and around art. This has happened most explicitly in some recent arguments for the existence of group artists, such as movie production teams and performance groups (Bacharach and Tollefsen 2010; Gaut 2010; Livingston 2011). These efforts come on the heels of a movement away from radical individualism in philosophy.2 Philosophers have begun think seriously about group agents and other kinds of collective entities (Gilbert 2013; List and Pettit 2011; Tollefsen 2015). It is already clear that there can be group artists. What I'm claiming is simpatico but distinct. Not only is there art by groups, but there is also art addressed to groups.

There is more here than simply the fact that we sometimes collect together to appreciate things as group audiences. Philosophers have already begun to explore the possibility of such group audiences. For instance, consider Tom Cochrane's discussion of joint attention in music - the way that paying attention together, with mutual awareness of each other's attention and enjoyment, is essential the experience of, say, a rock concert (Cochrane 2009). However, the notion that an artwork can address a group is quite distinct from the notion that an artwork can be experienced by a group audience. Cochrane has argued, convincingly, that in many cases we engage with an artwork as a group. My claim is that, in some cases, the meaning of an artwork is addressed to a group. And these are separable phenomena. A Tchaikovsky piano concerto is best engaged with as part of an attentive group, but each individual audience member can and should interpret that work in their own way, arriving at their own sense of the

I I am referring here to Romantic and modernist aesthetic theory, whose legacy is dominant in analytic aesthetics. For a summary of the individualist tendency, see (Hein 1996). Sociology and certain branches of critical theory can tend to make the opposite mistake - they take all art to be largely understood at the group level. In that case, one might take the arguments I give to establish a useful way to hinge between a sense in which some art is primarily addressed to groups, and other art is primarily addressed to individuals. However, this paper takes as its primary audience analytic aesthetics and analytic philosophy on the nature of groups, and so will focus on disputing the individualist tendency.

'See, for example, recent work on the social embeddedness of knowledge, and extended cognition (Goldberg 2010; Gallagher 2013; Clark 2008). 
meaning of the work. On the other hand, many monuments and memorials may be engaged with through solitary encounters by lone individuals, but their meaning is primarily aimed at some collective entity of which that individual is a part. James E. Young, for example, charts many profound experiences of Holocaust memorials which he encountered on his own, but which are, he suggests, meant to etch something into collective memory (Young 1993).

There are many cases where artworks and other works demand appreciation by group audiences. To my mind, plausible candidates include monuments, socially extended games like Magic: the Gathering, some avant-garde social art, ${ }^{3}$ built urban spaces, rock concerts, and architecture. But I would like to highlight a different set of cases, where an artwork is best understood as speaking to a group or collective entity. Those cases include monuments, memorials, anthems, fashion, and some street art. ${ }^{4}$ I will call art which demands appreciation via group engagement art through groups, and I will call art which speaks to groups art for groups. Of course, these categories can overlap, but it is worth keeping them distinct. ${ }^{5}$

In showing that art can play a role in the inner lives of group agents, I intend to advance two claims at once. First, I hope to show how art can function as a vessel for emotionally-laden group attitudes. I think this will help us start to come to terms with, not just the group agency of official institutions organized around explicit bodies of policy, as we find with nations and corporations, but the agency of less sharply defined groups, such as neighborhoods and musical subcultures. The latter sorts of groups are plausibly organized around more emotional expressions of value. Likely, in such groups, the use of art will not be incidental. We should expect to find artworks functioning as primary load-bearers in sustaining a group's long-term commitments, and in enabling a group to engage in emotionally informed practical reasoning. Second, I hope to show that there is,

${ }^{3}$ I mean to include movements such as the one known as Relational Aesthetics, and what has been come to be called social art (Bourriaud 2002; Bishop 2004, 2012; Finkelpearl 2012; Jackson 2011) . I offer an extended analysis of those types of artworks elsewhere (Nguyen forthcoming).

${ }^{4}$ I accept Nick Riggle's account of street art, by which it is distinctive as the art whose primary artistic resource is the street, where "the street" is essentially publicly available cultural space (Riggle 2010). Notice that my claim is distinct. Monuments and other public art may be presented in official settings, very much outside of the street, but yet still be addressed to the public.

s The debate over the nature of what is called "public art" has occasionally suffered from the unwillingness to distinguish between some very different phenomena: group as speaker, group as spoken to, group as spoken for, and individual as spoken to via a group experience. Consider, for example, the discussion over whether Richard Serra's Tilted Arc is really public art, which typically presumes that public art must speak on the behalf of the public (Kelly 1996) 
indeed, a category of art primarily addressed to groups. And I hope to show that the category of art for groups is not a minor footnote, but a central feature of communal and national life. The first thesis is likely more relevant to those interested in the nature of group agents, and the second to those interested in aesthetics. But I also hope my discussion will to help demonstrate how deeply interconnected these topics are to one another.

I cannot offer anything like a complete accounting of all the ways that art could speak to groups and all the ways that groups could use art. This domain is vast and shockingly unexplored. I propose, instead, that we try to get a handle on the category by beginning with a case study: that of monuments and memorials. I don't take these to be the only case of artistic guidance for groups, nor the only case of art for groups, but they are a good place to start. For one, monuments and memorials are generally acknowledged to be a kind of artwork, so we can avoid some of the more tedious disputes about the definitions of those terms. And the relationship of monuments and memorials to groups - their public origination and their public orientation - is well-documented. Monuments and memorials will function as a kind of conceptual spearhead to break into the terrain of art for groups, and an exemplar of how art can function in the emotional lives of groups.

\section{Commitments made concrete: a proposal}

Let me begin by making a proposal, without defense and relying on intuitive uses of some key terms. Once the proposal is in place, I will back up and fill in the details concerning group agents, collective entities and collective values.

Monuments and memorials are an essentially social, public, and functional form of art. Arthur Danto begins his famous review of the Vietnam Veterans Memorial:

We erect monuments so that we shall always remember, and build memorials so that we shall never forget. (Danto 1985)

Nick Wolterstorff, drawing on Young's art historical analysis of Holocaust memorials, makes memorials a central part of his case for functional art. In Wolterstorff's account, the museum practice of art - making works for disinterested aesthetic consumption - is but 
one particular practice in a cluster of art practices. Elsewhere in that cluster, we can find socially and practically embedded forms of art, including work songs, which ease the burden of labor, and social protest art, which seeks to enact change. Memorial art, says Wolterstorff, is the functional art practice of honoring, revering, and preserving in cultural memory (Wolterstorff 2015, 123-151).

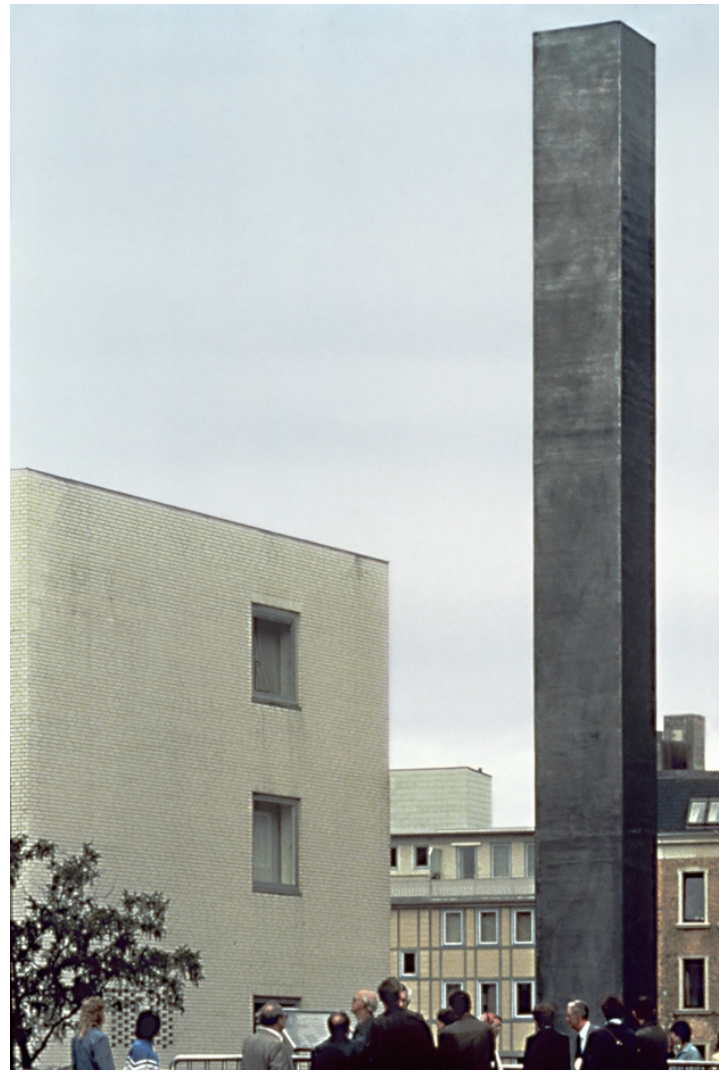

Figure 1. The Monument Against Fascism, as it was first unveiled. Images courtesy of Esther Shalev-Gerz. 

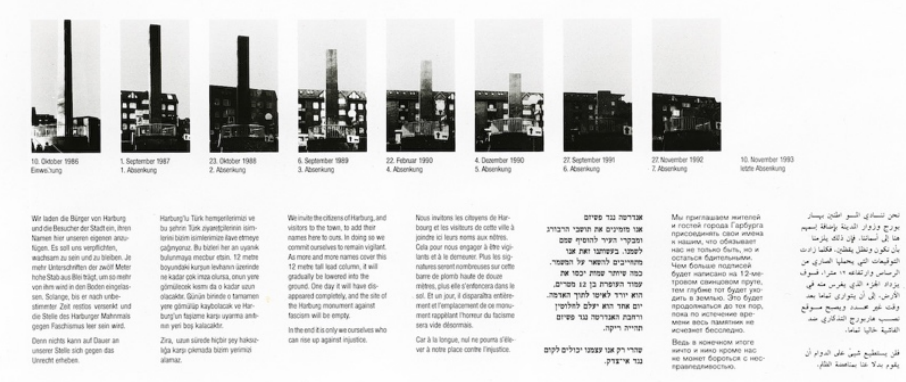

Figure 2. The monument is slowly lowered into the ground over the course of seven years.

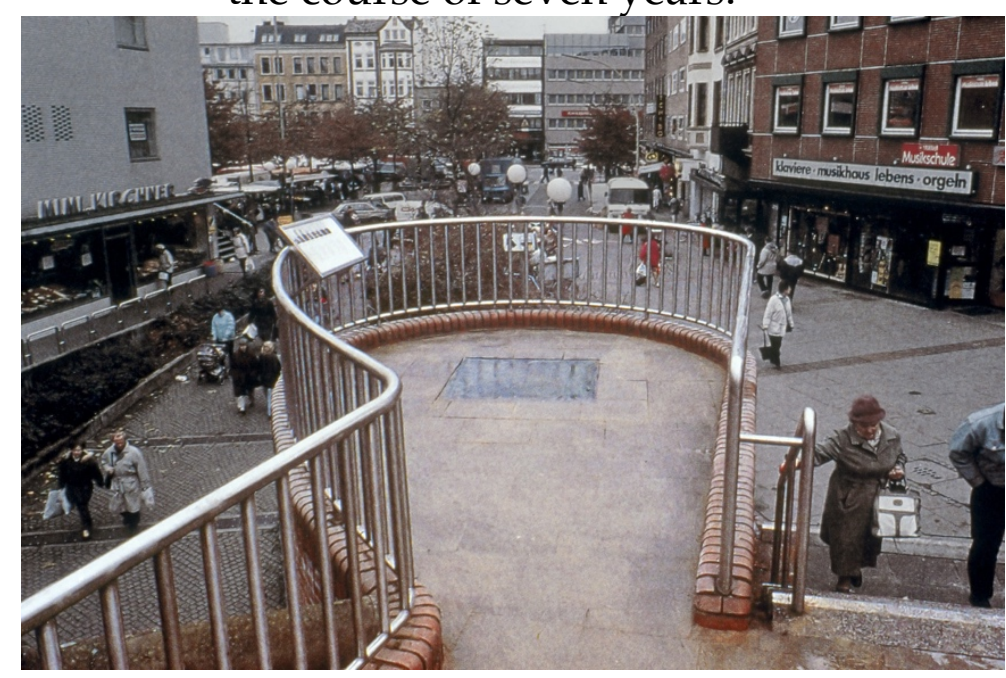

Figure 3. The site of the Monument Against Fascism, after the monument was entirely buried.

The top surface of the monument remains visible, flush with the ground.

But I think this isn't the end of the story. In The Texture of Memory, a landmark survey and analysis of Holocaust memorials, Young describes Esther Shalev-Gerz and Jochen Gerz's remarkable Monument Against Fascism. In 1979, during an upsurge of Neo-Fascist activity, the city of Hamburg began a public dialogue to construct a monument 
against fascism. The city government held an international competition, eventually selecting Esther Shalev-Gerz and Jochen Gerz's proposal. The Monument Against Fascism was erected in 1986 in Harburg, a borough of Hamburg. It was a tall metal column - one meter square and 12 meters high - clad in lead, and installed in a busy public square (see Figure 1). Residents and visitors were invited to engrave their names into the side of the monument, as a declaration of their intent to stand against fascism. After names had completely covered the accessible surfaces, the monument was lowered several feet into the ground, making new surfaces available for inscription (see Figure 2). After seven years of gradual lowering, the monument finally disappeared into the ground. Now, at the site of the monument, one can still read the original text and see photos of the monument in various stages of lowering. One can also stand on the top of the monument itself. Only the top surface remains visible, flush with the ground; the rest of the column lies buried beneath (see Figure 3) (Young 1993, 2837).

The text reads:

We invite the citizens of Harburg, and visitors to the town, to add their names here to ours. In doing so we commit ourselves to remain vigilant. As more and more names cover this 12 metrehigh lead column, it will gradually be lowered into the ground. One day it will have disappeared completely and the site of the Harburg monument against fascism will be empty. In the long run, it is only we ourselves who can stand up against injustice.

The Monument Against Fascism makes explicit what many other monuments leave implicit. The Monument Against Fascism asks its viewers to make a commitment to a future action: to remain vigilant against fascism. In other cases, the commitment can take the form, not of a call to a specific action, but of a commitment to some value, as a general guide to action. Take, for instance, the Political Martyr's Monument, a mottled obelisk of moderate height standing on Edinburgh's Calton Hill. Its particular placement on the hill makes it seem, somehow, less imposing and more nobly weary. One side of the monument contains a dedication 'to the memory of' of five martyrs, including Thomas Muir and William Skirving. The five had been tried and

${ }^{6}$ http: / / www.shalev-gerz.net/?portfolio=monument-against-fascism 
exiled in 1793 for campaigning for universal suffrage and parliamentary reform; several of them died in exile. Another side of the monument are inscribed two quotations:

"I have devoted myself to the cause of The People. It is a good cause-it shall ultimately prevail-it shall finally triumph. Speech of Thomas Muir in the Court of Judiciary on the 30th August 1793.

I know that what has been done these two days will be ReJudged. Speech of William Skirving in the Court of Judiciary on the 7th January, 1794."

The choice of quotations is crucial. The monument doesn't simply honor these people in some abstract way; it honors them specifically as martyrs to a cause, and through honoring them expresses solidarity with that cause. Though Danto and Wolterstorff have some of the story right, I think that their accounts are incomplete. Their accounts center on how monuments can preserve and honor something in memory. But monuments and memorials are not only backward-looking; they can be forward-looking and action-directing. They can express commitments to some value or cause; they can enshrine a commitment to act. These can include commitments honoring particular individuals - to keeping their memory alive and preserving a sense of their value. But there can also be forward-looking commitments, such as to standing together against fascism, or to the value of political action towards universal suffrage.

So here is my proposal. Monuments can be group-level artistic acts in two important ways. First, a group can use a monument as a vessel for group expression. Second, monuments can be artistic acts addressed to groups. Group-level entities - nations, cities, and less official collective entities - can be the primary intended recipient of a monument's meaning.

These possibilities can come apart. An individual can make an artwork to address a group - as an artist might, when they make a mural addressed to a whole community. A group can use an artwork to address an individual or another group - such as, for instance, when a nation places a menacing statue at a border, facing outwards. But an

' I do not mean to imply that I think that all artworks have meanings, or are valuable thereby. But it seems clear that monuments do usually have meanings. 
artwork could also be used both for group expression and group address. This opens up a fascinating possibility: that an artwork might be a way for a group to talk to itself, and so play a crucial role in that group's long-term deliberative process. In particular, a monument can be a way for a group to commit itself to something - a way of concretizing that commitment. This is as a group-level analogue of something individuals do all the time.

We often commit ourselves to courses of action. ${ }^{8}$ But we also give ourselves concrete reminders of those commitments. Some are simple and explicit, like the Post-It note on my bedroom mirror that says, 'Believe in Yourself'. Some are traditional and symbolic, like the wedding ring which symbolizes my commitment to my spouse. Some are personal and obscure, such as the self-inking 'You Shall Not Pass' rubber stamp, complete with an icon of Gandalf raising his staff, which I keep on my office desk - which, perversely, I placed there to remind myself to be compassionate to my students. We mark such commitments in all sorts of ways, by inscribing them into our world and sometimes our own bodies, through photographs, mementos, jewelry, or a dramatic haircut. Sometimes we make such objects expressly for the purpose of our expressing our own commitment, as with my PostIt Note. Sometimes we select objects made by another for use as a marker of commitment, such as a wedding ring or a store-bought motivational poster. And sometimes we take objects made for some entirely other purpose, and repurpose them as a concretized commitment - like with my rubber stamp.

Monuments and memorials, I suggest, can serve as a similar sort of physical instantiation, but for group commitments. They can be used by a group to talk and think to itself across time and over generations - to make some value concrete for itself, to keep it close. Some of those commitments may be to general values, such as freedom or equality. Others may be commitments to remember, honor, or condemn a particular person, community, or event in some value-laden way. And such physical repositories play a more integral role in group commitment than they do for personal commitment. How else would

\footnotetext{
s Some have worried that there is no such thing as commitments to self. According to Jon Elster, for example, the only kinds of personal commitment we can make are those that are causally actualized - actually tying ourselves to the mast before we see the sirens, or throwing the cigarettes out of the house (Elster 1977). I am persuaded by Bruno Verbeek's response, which defends the existence of internal rational commitments. Verbeek draws on Michael Bratman's work on planning, and argues that the possibility of internal rational commitment is a pre-requisite for making plans (Verbeek 2007).
} 
a group hang on to its commitment to the subtler forms of value? Some crucial values are slippery; they function to guide action, but are hard to express in explicit statements. Individuals can at store such subtle values in memory. But they are hard to pass between individuals, and so hard to hold on to as a collective.

But art is good at expressing such subtle values - at containing them, concretizing them, and preserving them. So if we think that a group might sometimes want to internally transmit more delicate and ineffable values, then we should look to that group's use of art, especially public art. And monuments and memorials, I suggest, are often clear examples of groups transmitting values and expressing longterm commitments. The commitment is partly expressed in the very concreteness of the monument and its expressively public placement. Art may serve individuals as a useful reminder of their values, but art can play an even more crucial role in group valuing. Art can serve as the primary repository for a group's subtle values. In this way, I will argue, art can enable the very existence of subtle group values.

I am not claiming that such self-commitment is the only use for a monument. Monuments can be used by a group for expressions aimed at individuals or other groups, and surely for all sorts of other things as well. But the self-committing function is, I think, characteristic of monuments.

None of this is to say that art intended for this purpose is guaranteed to be any good in moral or artistic terms, or genuinely representative of a group's real intentions. First, nothing about the proposal says that group commitments are guaranteed to be morally praiseworthy ones, or that the ensuing art is guaranteed to be expressive of good values. In fact, we should expect bad groups to make bad commitments and we should expect the art that enshrines those commitments to be morally horrific. This is the right way to think about Nazi monuments, and, say, self-congratulatory national monuments to victory in unjust wars. Furthermore, many monuments express nothing more than some group's bland self-congratulatory valuations - its commitment to loving itself in some simpleminded way. But this shouldn't surprise us, either; individuals also concretize plenty of inane commitments, like all those trite motivational posters and banal slogans. The vapid valuational content of many real-world monuments doesn't show that there's anything wrong with my account. It only speaks to the moral mediocrity of many actual groups, and the 
impoverished values to which they have chosen to commit themselves.

Finally, nothing about the proposal guarantees that the process of monument-making will be democratic. In a fully democratic society, we should expect monuments to properly represent the commitments chosen by the whole group. But in an authoritarian, or otherwise democratically failed, society, we should expect the official monuments to represent themselves expressing some group commitment, without actually proceeding from a legitimate process of group deliberation. That is, we should expect such monuments to falsely represent themselves as the product of genuine group assent. In fact, this explains precisely why monument creation is so often fraught with controversy. It is because monuments present themselves as expressing group commitments that it matters so much to the group members that they get it right.

\section{Are monuments really groups talking to themselves?}

I do not take this proposal to be an entirely original one, especially for the world outside of philosophy. Artists, art historians, sociologists and anthropologists often speak of monuments as repositories of collective memory. But for a certain stripe of hard-edged reductionist, all such talk of group memory and collective consciousness is simply fanciful metaphor. Let us address such skepticism directly. If one is inclined to think that there is no such thing as group agency at all, and that all actions and attitudes are best ascribed to individuals, then my claim is obviously wrong-headed. ${ }^{\circ}$ But recent work on the nature of group agency has given us the tools to resist such skepticism. More importantly, the exchange will help us to clarify art's role in the emotional lives of groups.

I am convinced by Philip Pettit and Christian List's claim that thinking in terms of group-level phenomena is crucial, especially when we are considering social interventions, such as how we might punish corporations, praise or condemn nations, or change our institutions' policies. Even if group-level phenomena are, strictly speaking, metaphysically reducible to individual phenomena, we

' Margaret Gilbert offers a useful summary of such skeptical positions in her discussion of collective guilt (Gilbert 2013, 229-237). My reconstruction of an opponent is based partially based on her discussion. 
cognitively finite beings cannot actually think in terms of the metaphysical ground floor. A parallel case: psychological phenomena are likely reducible to the activity of individual neurons, but in order to actually interact with people, we must think in terms of person-level phenomena: intentions, beliefs, choices, and actions. Similarly, we cannot actually think in terms of individual persons when we consider large-scale social phenomena. We must think in terms of group beliefs, group intentions, and group aims in order to decide how to act towards governments, corporations, and communities (List and Pettit 2011, 59-78; Pettit 2014a).

One might then accept that group agents are possible, but still resist the particular claim that monuments can be used by groups to address themselves. On the one hand, it is a commonplace to think that many kinds of art speak to and for communities. But perhaps these are simply fanciful metaphors. Perhaps the notion that an artwork might 'speak to a community' is simply shorthand for its addressing all the individuals in a community. Similarly, perhaps the notion of an artwork's being used to 'speak for a community' is simply shorthand for many different individuals assenting, as individuals, to the monument's speaking for them. Why should we accept the more radical claim that such art might be literally addressed to or from some collective entity?

Modern theories of group agency offer a useful way to differentiate between the beliefs and declarations that are attributable to individuals and those that are attributable to groups. Suppose all the individual members of the American Medical Association happen to believe in climate change. Still, we can't attribute to the AMA a collective belief in climate change. It takes something more: the AMA must go through a certain procedure and vote. We can attribute to the AMA a belief in the efficacy of vaccines because such a belief has been ratified through the appropriate organizational procedures. What's more, the President of the AMA might sign such a statement, and it might be read out loud by a spokesperson, but the belief ought not be attributed primarily to the President or the spokesperson. The spokesperson and the President are merely representatives. The belief is best attributed to the group, since it emerged from the group's structural procedures. And it is important to make those attribution properly, in order to best locate responsibility and aim our interventions (List and Pettit 2011, 19-80). If a group can designate a spokesperson as 
speaking for a group, then surely a group can designate a monument as expressing the group's beliefs, intentions, or commitments.

That designation can occur in different ways. A group could adopt a pre-existing artwork as representative of its attitudes, or a group could custom-make its own artwork for the task. Let's start with the possibility of adoption. In these cases, there is an artwork that has been made by some other entity - some individual or even some other group. Just as I might read a poem from Emily Dickinson to my beloved and then say, 'This expresses how I feel about you,' a group can select an artwork by some distinct artist and stand behind that work's expressive content, designating it as a group expression.

There are many ways in which a group could go about sourcing its adopted artworks. A group could, for example, hold a contest and pick whichever proposal it thought best expressed its values. Alternately, a group could adopt a conventionally authored work. For example, we might think that Russians eventually came to take Dostoevksy's and Tolstoy's novels as expressing their national values and character. An artist might make an artwork independently, hoping that it would eventually be adopted by a group. This, I think, is the right way to think about Maya Lin's Vietnam Veterans Memorial. It was at first only the work of an individual artist, which was then selected by an independent and private panel. It only eventually came to be accepted by the nation as a way to remind itself of, and commit itself to, a value. Here's Danto's description of the selection process for the Vietnam Veterans Memorial:

The winning design was the unanimous choice of a panel of eight experts, and it was accepted by the group that pushed the idea of a memorial as an expression of the feelings they wanted to have objectified. It gave a form to those feelings, as public art is supposed to do: the issues are never solely esthetic. It was accepted by 150,000 participants at the dedication. No one has defaced it, no one has tried to blow it up, though there was a threat of this once. It has been accepted by the nation at large, which did not even know it wanted such a memorial. It is now one of the sites most visited in the capital. (Danto 1985, 154)

At its conception, the memorial did not yet speak for the American public. Maya Lin was aiming at capturing something in the air, at giving voice to something in the public mind, and the panel of judges 
took themselves to be choosing on the public's behalf, but neither acted with the public's cooperation or consent. Over time, however, that public seems to have accepted the monument as an expression of their feeling (Kelly 1996). The monument, when it was unveiled, seems best thought of as merely a proposed group commitment. And, in this case, the nation as a whole does seem to have eventually endorsed the commitment as their own.

Let's turn to the second possibility for group expression via an artwork: that a group might itself make an artwork for the sake of expressing its attitudes. Here, the group would function as the artist of its own expressive artworks. But is this really plausible? Could communities and even nations ever count as group artists?

In Bacharach and Tollefsen's account of group artists, a group artist forms when individuals commit to some artistic endeavor as a body, intending to work together to achieve some artistic end. Their account distinguishes between mere artistic contributions and genuine members of a group artist. Consider a film production team. Some members of that team are mere artistic contributors. The on-set caterers may all contribute substantially to the film's quality, but they aren't part of the film's group artist, because they aren't part of the cooperative project of fixing the particular artistic properties of the work. The actors, the editor and the set-construction team, on the other hand, are all part of the group artist because they take themselves to be acting together to fix the particular artistic properties of the work (Bacharach and Tollefsen 2010, 28-30). I take this account to be quite plausible. The account helps to show how communities, and even nations, could function as group artists.

Suppose a community's political representatives decide to erect a monument that enshrines a certain value. They gather public input on various proposals, and select the one that best fits the values which the group wishes to express. That proposal's designer then creates mock-ups which are sent back to the representatives and the community for feedback and commentary, which in turn guides the designer's continued development. In this case, the designer and community are coordinating to work together to create an artistic product that expresses the community's values. They are functioning together as a group artist. The designer is acting as something like a lens for the group's intent, trying to find a good expression for that group's value while being responsive to the group's aesthetic input. In doing so, they are coordinating with the community to fix the particular 
artistically expressive qualities of the work..$^{10}$ Thus, if the elected representatives of a city government take an active role in providing aesthetic feedback and making aesthetic decisions, then they are a part of the group artist. And insofar as the city's entire populace is participating in the process via those elected representatives, or via direct input, then they are also part of the group artist.

Notice, here, that the issue of who the group artist may turn out to be crucial for the debates concerning the removal of monuments - especially if one accepts, as Sherri Irvin argues, that the artist holds the primary rights of revision over an artwork (Irvin 2005). In that case, it would matter very much whether the artist was a single individual, long passed away, or whether it was a nation or community that was still very much in existence, and actively engaged in the act of choosing which commitments to retain, and which to abandon.

In any case, let's return to the broader picture. My claim has two parts: that artworks can be expressions from groups, and that artworks can be addressed to groups. So far, I've shown only that groups can express themselves using artworks. This is, in fact, the easier task, given the resources of contemporary accounts of group agency. Under such accounts, we can attribute attitudes to a group - like beliefs, goals, and intentions - when they arise from the organized decision procedures of a group. It is relatively easy to pick out group expressions, because they are obviously the result of organized group action. It will be a harder task to show that art can be addressed to groups, especially if we are looking to cash out that address in terms of some sort of group experience or group appreciation. Perhaps, someday, we will have the theoretical resources to show how group agents can have their own distinctive form of aesthetic appreciation. But, in the meantime, we already have the means at hand to show that there is, at least, one way in which artworks address groups.

Monuments, I've claimed, are works of art that enshrine commitments. Such art presents a particularly good exemplar of art addressed to groups, because such art plays a clear role in guiding group action and in group-level practical reasoning." We can recognize group goals and values, because they arise via distinctively group

${ }^{10}$ (Young 1993) charts many variations on this theme in the creation of Holocaust memorials.

${ }^{11}$ For more on how groups can be said to reason, see (Rovane 2014; Tollefsen 2015). A particularly robust version of the claim will be that groups can constitute extended minds - for an overview, please see (Huebner 2011). However, one does not have to subscribe to such a radical hypothesis to think that one can attribute beliefs and reasons to groups; Pettit and List's account of group agency, for example, carefully avoids any such commitment. 
procedures of deliberation, and are meant to motivate distinctively group action. When art addresses itself to such group goals and values, then such art is best thought of as addressed to a group. Similarly, when an artwork aims to instill, inspire, or preserve a distinctively group value, it is also best thought of as addressed to a group.

To make this clearer, let's consider a few different accounts of collective entities and collective value, and show how, under each of them, there can be art for groups. I don't think these different accounts are incompatible; instead, I think they describe different sorts of collective entities, and that each will help us show a slightly different way that public art can be aimed at groups. The spread of theories will be instructive.

First, Bryce Huebner and Marcus Hedahl offer an account of robustly shared values. Robustly shared values imply a stronger cooperative structure than the values which people simply have in common. The residents of North Dakota may have some values in common: a love for wide-open spaces, hills, and buttes. But, say Huebner and Hedahl, these values are self-contained; they don't essentially depend for their success on how other people are valuing things. These residents are pursuing the same things in each other's vicinity, but they aren't pursuing them together (Searle 1983, 3-4). A robustly shared value, on the other hand, has a more explicitly cooperative structure. The value and its enactment depend on the value's being shared. The value of community, for example, can only be achieved by our pursuing it together (Huebner and Hedahl 2017).

Public art is well-suited to expressing shared values. Consider the difference between a privately displayed statue and a monument standing in a public square in front of the town's courthouse. A privately displayed statue may move me, reminding me of my commitment to some value, and so help me to renew that commitment. But the public monument does something more. Not only might it move me to renew my commitment to a value, but I can also count on other people to encounter it, and I can reasonably hope that many of them will be similarly moved. Thus, monuments play a role in expressing and aiding in our grip on shared values as shared. If I value the democracy of my country, surely I value it as shared. It is a value that can be realized only when it is shared, and through being shared. A monument expressing a commitment to democracy can, in a very special way, help grow a shared value precisely because of its public display and the public process of its creation. 
Next, consider Gilbert's account of group agents as constituted by a joint commitment. Says Gilbert: a joint commitment forms when individuals commit themselves to doing something together as a body. This commitment can be towards various sorts of projects, from simple ones, like taking a walk together, to complex ones, like sustaining liberty for all (Gilbert 2013). But a joint commitment is a group-level phenomenon. Individuals can't create a joint commitment independently, and a joint commitment creates obligations from which individuals can't excuse themselves of their own accord. This gives us another pathway to art for groups: an artwork is addressed to a group if it addresses itself to a joint commitment, rather than to an individual commitment.

What might that be like? Consider two different pieces of street art. One is a small painting of a lonesome puppy, hidden in the dark corner of a pedestrian tunnel. It is painted so that most people speeding through, absorbed in their daily routine, will pass it right by. But occasionally some lone wanderer might stumble across it, and the very unlikeliness of their discovery might make it feel special. They might entertain the possibility that they alone have noticed it, and this possibility might be deeply gratifying. Their appreciation is solitary, and it is enhanced because it is self-consciously solitary. Imagine, on the other hand, a massive piece of anti-gentrification street art, emblazoned over an aging apartment building. Imagine that the artwork protests, in graphic and emotionally charged terms, the new Amazon Whole Foods being built right beneath it, calling on the neighborhood to fight back. This piece of street art seems aimed at electrifying a community, at moving them to act collectively. The members of the neighborhood may have a pre-established joint commitment to maintain a certain feel to the neighborhood, a certain intimacy or warmth, a certain degree of affection. The anti-gentrification street art is trying to speak to that joint commitment, to channel it into a particular group action. The artwork is pointing out that the Amazon Whole Foods violates the standing group commitment, and calling on the neighborhood to, as a body, to be moved by that commitment and cast out the Amazon Whole Foods. If that street art is calling on, trying to speak to, or trying to channel a joint commitment, then it is addressed to a group. Similarly, an artwork can propose a new joint commitment. This is, I think, exactly what is going on with the Monument Against Fascism, which proposed that people commit to collective vigilance against fascism. 
Finally, consider Pettit's and List's account of group agency. For them, an agent is something that has representations and motivations, which interact to bring about actions. Obviously, individual humans count as agents. Groups also count as agents when there representations and motivations which are best attributed to the group rather than to any individuals (List and Pettit 2011, 19-41; Pettit 2014b). For example, the IRS is a group agent. It has beliefs that are best attributed to the IRS as a whole, rather than to an individual. The IRS may believe me to be a good taxpayer, but that belief consists of different bits of records scattered across the organization, and an institutional system which retrieves and assembles those records. No single person has enough information to be attributed with that belief; that belief can only be attributed to the IRS as a whole. Furthermore, the IRS has motivations, in the form of policies. Together, the group's beliefs and motivations lead the group to collect taxes, punish individuals that seek to evade taxes, etc.

Such group agents can also have values. Keith Graham offers us a useful formulation of 'values': values are the thoughts which inform practical reasoner's decisions about how to act, about what states of affairs are worth realizing, and about what objectives are worth achieving (Graham 2002, 12). Group values, then, are whatever plays an analogous role in informing a group's decisions. Surely the Declaration of Independence and the US Constitution express values which play such a role in America's internal decision-making process. Similarly, the mission statement of a university contains group values, since it can guide individuals when they act for the group. An artwork, then, might be said to address a group if it were primarily aimed at instilling, altering, or otherwise speaking to group values, rather than individual ones.

But, one might protest, artworks must still be experienced by individuals. Let's suppose, for the moment, that this requirement holds. Even so, it would present no barrier to the claim that an artwork might be primarily aimed at influencing a group's values or commitments. Consider: the best explanation for a piece of institutional policy might be that it expresses a group value. In order to be translated into action, that policy needs to be read, experienced, processed, and acted on by individuals. But that policy might still be best understood as a group belief or the expression of a group motivation, especially if its primary function is the guidance of organized group action. 
Though I have been using as my central example a group using art as part of its own internal deliberative process, that is not the only example of art for groups. Groups can address other groups through art. What, after all, is the Statue of Liberty but one group agent, France, addressing another group agent, America, through an artwork? It is France offering a concretization of a commitment to a certain vision of equality and justice, and offering that concretization in a form intended to to guide the future of the addressed group. Individuals can also address groups through art. Murals and street art, for example, often begin their lives as attempts, by an individual to try and shape the collective values and the collective intentions of some community. At first, they are merely individual declarations, addressed to a group. But over time, the group can come to express and stand behind that individual artistic act. Some murals become 'part of the neighborhood' - a point of community pride, watched over and protected by the neighborhood. The group has, over time, come to adopt an individual declaration as a group commitment. The nature of street art may make it particularly amenable to a communal selection process. Street art is, by its very nature, public - it is in the public domain and usually open to public modification (Riggle 2010). If any piece of street art persists, it persists only because passers-by refrain from altering it. Suppose we were in an urban area where residents regularly cleaned off unwanted graffiti, and where local artists regularly painted over older street art with newer pieces. The very persistence of a piece of street art, in these circumstances, can constitute evidence of the approval of that community, as expressed through the community's members consistently refraining from damaging it. In this way, street art might function as the basis for an informal, communal deliberation - thought that possibility calls for further exploration ${ }^{12}$.

\section{Art and the possibility of group emotion}

\footnotetext{
${ }_{12}$ Much of the literature on group agency as focused on formally organized institutions, such as corporations and nations. Elsewhere, Matt Strohl and I have argued that there are other reasons to think that such informal groups exist, and good reasons to develop better accounts of them then are currently available in the literature. We suggest that resolving particular cases of cultural appropriation will usually depend on resolving the beliefs of informally structured group agents, such as cultural communities (Nguyen and Strohl 2019).
} 
But why pick out art in particular? Don't we have other ways for groups to speak to themselves and to express their values and commitments? Certainly, institutions have all sorts of ways to store beliefs in institutional memory and to commit to institutional values. There are mission statements for universities and corporations and constitutions for governments. What more do we need? What special role might art play in the inner lives of groups?

This hovers near a longstanding question about the difference between the communicative power of art and the communicative power of less artful, more explicit forms of expression. Art, it is usually thought, has the power to communicate certain things that are too slippery, ineffable, or inchoate to be captured perfectly in unartful propositions. Let's focus, for the remainder of the paper, on one particular sort of hard-to-express attitude: emotional ones. ${ }^{13}$ Art has a particular power is to capture and express emotions in a delicate, nuanced, and sensitive way. ${ }^{1}$ So if we wanted, as a group, to commit ourselves to a particularly emotional way of understanding or to an emotional value, one way to do that would be through an artwork.

Why might a group agent want to do such a thing? The answer might be: because emotional guidance has some special and desirable features. For most individual agents, emotions play a crucial role in their understanding of the world and their practical reasoning about it. Such agents are crucially different from emotionless ones. At the very least, we might think those groups are a little more recognizably human. But we might also think something more radical: that welltuned emotions play a vital role in a sensitive moral life and that emotionally-guided agents are capable of greater sensitivity and finer moral judgment. We might think that, if a group was emotionally guided in the right way, then it, too, would be capable of more richly virtuous group action. Emotions, however, are notoriously hard to express. In order for a group to be guided by emotions, it would need some medium in which it could contain, preserve, and express these emotions - a medium which could make such emotions publicly accessible. Art makes it possible for group agents to guide themselves

${ }^{13}$ Another pathway that deserves exploration is how art could guide groups by transmitting understandings that cannot be easily expressed otherwise. Catherine Elgin provides a useful account of how art, through metaphor, can transmit subtle understandings of the world (Elgin 2002).

${ }^{14}$ The literature on this is vast. For useful entry points, two authoritative accounts, with useful surveys of the literature, are Jenefer Robinson's and Derek Matravers' (Matravers 1998; Robinson 2005). 
with emotions and emotionally-laden values. ${ }^{15}$ I do not claim that art is the only way to publicize an emotion - but they are surely one of our primary methods to achieve such publicity, and so one of our primary tools for enabling emotional group agency.

Others have noticed the pressure to find a public form to contain an emotion, but have not availed themselves of the possibility of artistic repositories of emotion. For example, Glen Pettigrove and Nigel Parson argue for the existence of collective emotions in the heat of the moment, such as group fear or group anger. But they do not think such group emotions can last. In order to have some sort of lasting effect, such collective emotions need to motivate 'the creation of lasting institutions and protocols' through which 'these emotions will be given a kind of permanence that will outlast the feelings of fear and anger that are part of the conscious experience of most of the individuals who make up the collective' (Pettigrove and Parsons 2012, 513). In other words, they think that group emotions need to be translated into a more explicit and less emotional form in order to survive over time. My suggestion is, instead, that art can function to inscribe the emotion itself, in some lasting form, and let it continue to offer guidance to the group and its members in a distinctively emotional way, without the need for translation into explicit protocols. Such art would then play a central functional role in the emotional life of a group.

Consider the crucial role of emotions in the practical lives of individuals. Emotions can guide our action, attention, and shape our values. Are there group emotions? Some theorists of group agency think that attributing emotions to groups is quite plausible (Gilbert 2013, 229-256). Others are more doubtful of the existence of genuinely collective emotions, especially in such loosely knit structures as communities (Huebner 2011). One reason we might doubt the existence of genuinely collective emotions is that we might require that emotions always have some felt, experiential character, and we might deny that groups can have such felt experiences at the collective level. I will assume, for the rest of this paper, the position of the doubters. I do this to focus on the particular and special logical possibility that art offers. Art makes it possible to attribute emotions to groups without

${ }_{15}$ There have been several accounts which have aimed to show both that emotions are an important method of self-guidance, and that art can be a good vehicle for transmitting those emotions. These include Martha Nussbaum's account of how narratives may transmit emotional understandings, and Jennifer Robinson's account of how emotions, conveyed through art, may change our attentional saliences and motivational states (Nussbaum 1992, 3-53,125-47,261-85; Robinson 2005). 
necessarily attributing felt emotional experiences to groups. Particular emotions can be designated as the group's - as guides for future group action - and those emotions can do so without needing to be collectively experienced in some sort of group consciousness. Instead, art can function as a public repository in which group-designated emotions can reside, and from which they can later be accessed. Even if emotions could only be felt by individuals, an artwork could store and revive that emotion, and be used by individuals to direct their choices when acting as part of the group. Thus, art can make group emotion possible, even if felt group experiences are impossible.

Call something a group-guiding emotion if it is an emotion which plays a guiding role in group deliberation and action - in the group's representations, motivations, and decisions to act - functionally analogous to how individual emotions can guide individual deliberation and action. Suppose that, for some group, when its members act in the name of the group or enacting their roles within the group, they are to do so while adopting some designated emotional state. That state would be a group-guiding emotion. Such emotions could reasonably and sensibly be attributed to a group without presuming that the group had any kind of collective experience or that it felt any sort of collective emotions. Recall that a policy could count as presenting a group's value if it is designated, by a group process, as an authorized guide for members as they perform their roles within the group. In the same way, an emotion can count as a group's if it is settled on through a group process, presented as the group's, and because being so presented serves to guide the group's further actions.

Thus, an emotion can be attributed to a group on the same basis for attributing a belief, intention, proposition, or value to a group. (I'll refer to these all of these as 'group attitudes'). There is no conceptual difficulty here. The primary barrier seems practical - in order for an attitude to be a group's, it must be transmissible across its members. An individual can recall their own emotions, but how could group emotions propagate between individuals and over generations? A difficulty for the existence of group-guiding emotions is that they must be entered into some public repository: first for group members to jointly commit themselves to, and then later for group members to access.

To understand this difficulty, we need to dig a little into the history of thinking about group agency. Many early accounts of group agency are summative. According to a summative theory, we attribute 
an attitude to a group when most or all members of the group hold that attitude. If we accepted a summative theory of group agency, it would be easy to attribute emotions to a group. The emotion merely need be felt in common; it need not to be publicly communicated. But most theorists of group agency now reject summative theories. As Gilbert puts it, in many cases we want to attribute an attitude to a group that many of its members don't hold - for example, when we delegate a sub-committee to investigate something and come to a conclusion in the name of the group. And in many cases, we don't attribute an intentional state to a group even though most or all of the members hold it. For example, even if all members of the American Medical Association love sushi, we wouldn't want to attribute a love of sushi to the American Medical Association. Rather, says Gilbert, a group acquires an intention when the members commit themselves to it, and because the members know that the other members have committed themselves to it. Such a theory is non-summative (Gilbert 1987, 2013, 23-57). In order for the group to commit itself in such a shared way to an intention, the intention needs to be made public, so the group's members can assent to it, and know that the others have also assented.

But many forms of public communication - especially those that must pass through the official procedures of committees, subcommittees, policy review, and legal oversight - seem unable to capture the nuance and delicacy of complex emotional understanding. The institutional language of policies and mission statements is usually bland, uninspiring, and bereft of any sort of motivational life. Consider my own university's mission statement, which dedicates the university to '[building] on a foundation of substantive scholarly and creative work to foster engaged learning. The university prepares professionally competent people of integrity who, as lifelong learners and leaders, serve as stewards of a globally interdependent community ${ }^{\prime}{ }^{16}$ We might drily take such a formulation into account when justifying an action to our bureaucratic overlords, but who in their right minds would actually be moved by such a thing?

Art offers us a better alternative. Artworks, because they can express nuanced and otherwise inexpressible intentions, values, and emotions, make it possible to publicize emotions, and so make it possible for an emotion to be the object of a group commitment. Art can

${ }^{16}$ From the Utah Valley University website, accessed February 15, 2018. 
give groups a means to hang onto their core values over time, even when those values are subtle and tinged with emotion.

Let's go even further. Art can not only help a pre-existing group hang onto a value; it can play a crucial role in the group's very act of emotional self-constitution. Art can offer a seed crystal around which a group might condense. Suppose that I live in an area of town that doesn't have anything like a life as a cooperating group. There is no sense of togetherness, no cooperative aim, and no shared value. But an artwork can suggest such a cooperative aim. It can encourage the group to come into existence by offering some sort of emotional seed crystal. After all, the problem with kickstarting shared values is that they need to start out as shared. One way to get them shared is to present them in some public manner, such as a mural. ${ }^{17}$ Obviously, that artwork cannot be made by the group itself. Instead, it will be the work of some individual artist or smaller group, proposing to a larger set of disorganized individuals that they join together as a group. And an artwork can do so by proposing a value in an artistic manner. Imagine, for instance, that my part of town is falling apart; nobody looks after anything but their own private property and their own lives. A mural might present us with an image of neighborliness - an image of what the neighborhood would look like if we came together as a community and looked after ourselves together. In other words, the mural presents us with a new shared value, and presents it such that its nature as shared is particularly prominent. Such a mural could help instigate a group into willing itself into existence. ${ }^{18}$ (This idea came from a conversation with a Philly Uber driver, who told me the story about how the Philadelphia Mural Society started hiring the kids who were making 'horrible, destructive' graffiti tags to paint murals about the neighborhood instead, and how those murals sparked a renaissance of local pride. ${ }^{11}$ And it seems plausible to think that murals, which we pass by every day as we walk through our part of town and which occupy the public space so concretely yet so vulnerably,

${ }^{17}$ I use the term "mural" here in specific contrast to the notion of "street art". Street art, according to Riggle, employs as an artistic resource the street, and so is by its nature open to intervention by others. Some murals do count as street art, but some do not - they exist on private property and are protected, though they are situated so as to be in the public space.

${ }^{18}$ I take some inspiration here from Virginia Held's discussion of those cases when loose collections of individual might be responsible for organizing themselves into a group (Held 1970).

${ }_{19}$ The Philadelphia Mural Arts Society makes similar claims in explicit terms. https: / / www.muralarts.org/about/. 
are much more likely to promulgate a shared value effectively than, say, some slogan cooked up by a civic pride committee.

This is not some mere philosophical fantasy; ideas like this occur explicitly in some artists' talk about their public art. Consider, for example, Joseph Bueys' public artwork 7000 Oaks. As it was originally conceived, the work involved seven thousand stones arranged around an oak tree. Individuals were supposed to purchase individual stones, thereby sponsoring the replanting of a single tree. Over time, the work would have brought about the communal reforestation of an entire region. Beuys himself says that the work was meant to awaken individuals to community action; the pile of stones was supposed to prefigure and instigate the creation of a coherent social structure (North 1990, 11).

And I suspect that once we start looking through our cultural lives for other such practices, we will find them everywhere. I have been invited a few times to a Passover Seder, in which certain foods are consumed and words are said specifically to remind the participants of the history of slavery and suffering of the Jewish people. Let me suggest that in participating as a non-Jewish guest, I have been invited to take on, for a moment at least, the values and commitments of another group, presented in a profoundly emotionally inflected way - to think about history from the perspective of a group that had suffered in a particular way, and held on to that suffering and honored it in a particular way. I glimpsed, as an outsider invited in for the moment, a practice designed to maintain the psychic identity of a group. The existence of the Seder, as with the existence of the Vietnam Veterans Memorial, helps make complex, nuanced, emotionally-valenced group perspectives available, and so helps make it possible for people to constitute and maintain themselves together as emotional group agents..$^{20}$

\section{Thi Nguyen \\ Department of Philosophy \\ Utah Valley University}

${ }^{20}$ I'd like to thank Sondra Bacharach, Kara Barnette, Anthony Cross, John Dyck, David Ebrey, Emily Fletcher, Bryce Huebner, Shen-yi Liao, Samantha Matherne, Jose Medina, Shannon Mussett, Nick Riggle, Brian Soucek, Matt Strohl, and Servaas van der Berg for all of their commentary, aid, and insight. I'd also like to thank Esther Shalev-Gerz for permission to use her images of the Monument Against Fascism. 


\section{Bibliography}

Bacharach, Sondra and Deborah Tollefsen. (2010). We did it: From mere contributors to coauthors. Journal of Aesthetics and Art Criticism 68 (1): 23-32.

Bishop, Claire. (2004). Antagonism and relational aesthetics. October Magazine 110:51-79.

—_. (2012). Artificial Hells: Participatory Art and the Politics of Spectatorship. Verso Books.

Bourriaud, Nicolas. 2002. Relational Aesthetics. Trans. Mathieu Copeland, Fronza Woods, and Simon Pleasance. Les presses du réel Dijon.

Clark, Alan. (2008). Supersizing the Mind: Embodiment, Action, and Cognitive Extension. New York: Oxford University Press.

Cochrane, Tom. (2009). Joint attention to music. British Journal Off Aesthetics 49 (1): 59-73.

Danto, Arthur. (1985). The Vietnam Veterans Memorial. The Nation. Aug 31, 1985: 152-155.

Elgin, Catherine. (2002). Art in the advancement of understanding. American Philosophical Quarterly 39 (1): 1-12.

Elster, Jon. (1977). Ulysses and the sirens: A theory of imperfect rationality. Information (International Social Science Council) 16 (5): 469-526.

Finkelpearl, Tom. (2012). What We Made: Conversations on Art and Social Cooperation. Duke University Press.

Gallagher, Shauna. (2013). The socially extended mind. Cognitive Systems Research 25-26:4-12.

Gaut, Berys. (2010). A Philosophy of Cinematic Art. Cambridge: Cambridge University Press.

Gilbert, Margaret. (1987). Modeling collective belief. Synthese 73 (1): 185-204.

_ . (2013). Joint Commitment: How We Make the Social World. Oxford: Oxford University Press.

Goldberg, Sanford. (2010). Relying on Others: An Essay in Epistemology. Oxford University Press.

Graham, Keith. (2002). Practical Reasoning in a Social World: How We Act Together. Cambridge: Cambridge , 2007. 
Hein, Hilde. (1996). What is public art?: Time, place, and meaning. The Journal of Aesthetics and Art Criticism 54 (1): 1-7.

Held, Virginia. (1970). Can a random collection of individuals be morally responsible? The Journal of Philosophy 67 (14): 471-481.

Huebner, Bryce. (2011). Genuinely collective emotions. European Journal for the Philosophy of Science 1 (1): 89-118.

Huebner, Bryce and Marcus Hedahl. (2017). Shared values, interests, and desires. In Routledge Handbook of Collective Intentionality. New York: Routledge.

Irvin, Sherri. (2005). The artist's sanction in contemporary art. The Journal of Aesthetics and Art Criticism 63 (4): 315-326.

Jackson, Shannon. (2011). Social Works: Performing Art, Supporting Publics. Routledge.

Kelly, Michael. (1996). Public art controversy: The Serra and Lin cases. The Journal of Aesthetics and Art Criticism 54 (1): 15-22.

List, Christian and Philip Pettit. (2011). Group Agency: The Possibility, Design, and Status of Corporate Agents. Oxford: Oxford University Press.

Livingston, Paisley. (2011). On authorship and collaboration. Journal of Aesthetics and Art Criticism 69 (2): 221-225.

Matravers, Derek. (1998). Art and Emotion. New York: Oxford University Press.

North, Michael. (1990). The public as sculpture. In Art and the Public Sphere. Ed. W. J. T. Mitchell. Chicago: University of Chicago Press.

Nguyen, C. Thi. (forthcoming). Games: Agency as Art. New York: Oxford University Press.

Nguyen, C. Thi and Matt Strohl. (2019). Cultural appropriation and the intimacy of groups. Philosophical Studies (174) 4: 981-1002.

Nussbaum, Martha C. (1992). Love's Knowledge: Essays on Philosophy and Literature. New York: Oxford University Press.

Pettigrove, Glen and Nigel Parsons. (2012). Shame: A case study of collective emotion. Social Theory and Moral Practice 38 (3): 504530.

Pettit, Philip. (2014a). Group agents are not expressive, pragmatic or theoretical fictions. Erkenntnis 79 (9): 1641-1662.

Pettit, Phillip. (2014b). How to tell if a group is an agent. Essays in Collective Epistemology. 
Riggle, Nicholas Alden. (2010). Street art: The transfiguration of the commonplaces. The Journal of Aesthetics and Art Criticism 68 (3): 243-257.

Robinson, Jenefer. (2005). Deeper Than Reason: Emotion and Its Role in Literature, Music, and Art. New York: Oxford University Press.

Rovane, Carol. (2014). Group agency and individualism. Erkenntnis 79 (9): 1663-1684.

Searle, John. (1983). Intentionality: An Essay in the Philosophy of Mind. Cambridge: Cambridge University Press.

Tollefsen, Deborah Perron. (2015). Groups As Agents. Cambridge: Polity Press.

Toumela, Raimo. (2007). The Philosophy of Sociality: The Shared Point of View. Oxford: Oxford University Press.

Verbeek, Bruno. (2007). Rational self-commitment. In Rationality and Commitment. Ed. Fabienne Peter and Hans Bernhard Schmid. New York: Oxford.

Wolterstorff, Nicholas. (2015). Art Rethought: The Social Practices of Art. Oxford: Oxford University Press.

Young, James E. (1993). The Texture of Memory. New Haven: Yale University Press. 